\title{
Arctic Climate Interventions
}

\author{
Daniel Bodansky \\ Regents' Professor, Sandra Day O'Connor College of Law, \\ Arizona State University, Phoenix, AZ 85004, United States \\ Daniel.Bodansky@asu.edu
}

\author{
Hugh Hunt \\ Reader in Engineering Dynamics and Vibration, Department of Engineering, \\ University of Cambridge, Cambridge CB2 1PZ, United Kingdom \\ hemhi@cam.ac.uk
}

\begin{abstract}
The melting of the Arctic poses enormous risks both to the Arctic itself and to the global climate system. Conventional climate change policies operate too slowly to save the Arctic, so unconventional approaches need to be considered, including technologies to refreeze Arctic ice and slow the melting of glaciers. Even if one believes that global climate interventions, such as injecting aerosols into the stratosphere to scatter sunlight, pose unacceptable risks and should be disqualified from consideration, Arctic interventions differ in important respects. They are closer in kind to conventional mitigation and adaptation and should be evaluated in similar terms. It is unclear whether they are feasible and would be effective in saving the Arctic. But given the importance of the Arctic, they should be investigated fully.
\end{abstract}

\section{Keywords}

Arctic - geoengineering - climate change

\section{Introduction}

The Arctic is melting and, using conventional climate change policies, there is little we can do about it. Even if we were able to eliminate all emissions of greenhouse gases overnight - an obviously impossible task - the Arctic would 
continue to warm for many years due to the climate system's inertia and positive feedbacks such as albedo loss and the melting of permafrost. ${ }^{1}$ By the middle of the century, if not much earlier, summer Arctic sea ice will likely be gone, with potentially catastrophic consequences not only for the Arctic itself, but for the planet as a whole. ${ }^{2}$

Given the urgency of saving the Arctic, and the inability of conventional mitigation policies to do so, unconventional approaches need to be considered, approaches using as yet untested (and, in some cases, undeveloped) technologies. In recent years, concern that emission reductions will prove insufficient to avoid dangerous climate change has led to increased interest in possible interventions in the climate system (sometimes referred to as 'climate engineering' or 'geoengineering'). Most of the attention has been devoted to global interventions either to remove carbon dioxide $\left(\mathrm{CO}_{2}\right)$ from the atmosphere or, more controversially, to reflect sunlight away from the earth. In contrast, this article considers the possibility of more limited, targeted interventions to save the Arctic, for example, by refreezing Arctic ice or slowing the melting of Arctic glaciers.

Like global climate interventions, Arctic interventions would not be a substitute for aggressive action to curb greenhouse gas emissions. And like global interventions, Arctic interventions raise understandable safety, governance, and legal concerns, which need to be addressed.

But even if one believes that global climate interventions pose unacceptable risks and should be disqualified from consideration, Arctic interventions differ in several important respects:

- First, they seek only to preserve the status quo - for example, by preventing Greenland glaciers from slipping into the sea or maintaining the thickness of Arctic sea ice - and hence raise fewer safety concerns than global interventions, which introduce new elements into the climate system, with potentially unpredictable effects.

- Second, to the extent Arctic interventions involve actions by countries within their own territory to protect their own resources, they raise fewer governance and legal issues than global climate interventions.

- Third, Arctic interventions would not pose a moral hazard, since they address only one aspect of climate change and clearly are not an alternative to global emission reductions.

1 Arctic Monitoring and Assessment Programme (AMAP), Snow, Water, Ice, and Permafrost in the Arctic: Summary for Policymakers (AMAP, Tromsø, 2017) 5 [SWIPA 2017]. Arctic warming of $4-5^{\circ} \mathrm{C}$ is 'locked into the climate system by past emissions and ocean heat storage, and would still occur even if the world were to make drastic near-term cuts in emissions'.

2 Ibid. 
- Fourth, to the extent international governance were deemed desirable for Arctic interventions, the Arctic Council could, in principle, serve as an assessment and policy forum, since it comprises the actors who have the primary interest in Arctic activities, including the Arctic circumpolar countries and indigenous communities.

Of course, these differences between global and Arctic climate interventions do not mean we should undertake Arctic intervention. But they do help to 'normalise' it, and support evaluating it in the same way we analyse other mitigation and adaptation options - in terms of its safety, effectiveness, and cost - rather than putting it in a separate category subject to special scrutiny.

In this article, we describe the crisis facing the Arctic, explain why it matters, survey the range of Arctic intervention proposals, and analyse these options from a policy and legal perspective. Since we know very little about Arctic interventions, what is most needed now is research. It may turn out that none of the proposed Arctic interventions is technically feasible, given the harsh Arctic environment. Even if they are feasible, they may not have a big enough effect to save the Arctic, in which case global climate interventions that provide greater leverage may be the only option. But, considering the importance of the Arctic, one should leave no stone unturned.

\section{Arctic Warming}

Climate change is usually described and assessed in terms of global mean temperature change. The headline number, for example, in describing climate change is the global mean temperature increase of roughly $1^{\circ} \mathrm{C}$ from preindustrial levels. Similarly, the Paris Agreement defines its objective as limiting global mean temperature increase to well below $2^{\circ} \mathrm{C}$, with an aspirational goal of $1.5^{\circ} \mathrm{C} .^{3}$

But global warming is not evenly distributed around the world. It is well established that the poles warm twice as fast as the global average. ${ }^{4}$ This polar amplification of global warming has already increased the temperature in much of the Arctic by more than $2^{\circ} \mathrm{C}$. As a result, Arctic sea-ice extent has declined by roughly $40 \%$ over the last 40 years, Arctic sea-ice thickness by $65 \%$

3 Paris Agreement (Paris, 12 December 2015, in force 4 November 2016), UN Doc FCCC/ $\mathrm{CP} / 2015 / 10 /$ Add.1.

4 Intergovernmental Panel on Climate Change (IPCC), Special Report on the Ocean and Cryosphere in a Changing Climate (Cambridge University Press, Cambridge, 2019) 205. 
from 1975 to $2012,{ }^{5}$ and Arctic sea-ice volume by roughly a half. ${ }^{6}$ Even the socalled Last Ice Area - the region's oldest and thickest ice - is melting rapidly, with its rate of ice-mass loss double that of the Arctic generally. ${ }^{7}$ The 2019 IPCC Special Report on the Ocean and Cryosphere (sRocc) concluded that the decline in Arctic sea ice is 'unprecedented in at least 1000 years.'

Even if the world achieves the Paris Agreement's well-below- $2^{\circ} \mathrm{C}$ temperature goal, the Arctic could warm by as much as $5^{\circ} \mathrm{C}$ by $2100 .{ }^{9}$ Some scientists estimate that this rapid warming is likely to lead to a summer-ice-free Arctic within the next several decades ${ }^{10}$ and describe the Arctic as in a 'death spiral.'.1

\section{Why Arctic Warming Matters}

The warming of the Arctic is of concern not only for the Arctic, but for the world as a whole, because of the Arctic's role in the global climate system. As the Second Arctic Assessment concluded in 2017: "With each additional year of data, it becomes increasingly clear that the Arctic as we know it is being replaced by a warmer, wetter, and more variable environment. This transformation has profound implications for people, resources, and ecosystems worldwide.12

AMAP (n 1), at pp. 4, 5 .

6 'PIOMAS Arctic sea ice volume reanalysis', Polar Science Center, University of Washington, Figure 11 (2020), available at http://psc.apl.washington.edu/research/projects/arctic-sea -ice-volume-anomaly; accessed 10 June 2020 (annual mean sea ice volume declined from $\sim 25,500 \mathrm{~km}^{3}$ in 1979 to $\sim 13,500 \mathrm{~km}^{3}$ in 2020); see also JC Stroeve, MC Serreze, MM Holland et al., 'The Arctic's rapidly shrinking sea ice cover: A research synthesis' (2012) 11o Climatic Change 1005-1027.

7 GWK Moore, A Schweiger, J Zhang and M Steele, 'Spaciotemporal variability of sea ice in the Arctic's last ice area' (2019) 46 Geophysical Research Letters 237, doi:10.1029/2019GLO83722. The 2019 US National Oceanic and Atmospheric Administration (NOAA) Arctic Report Card found that the oldest ice (>4 years old) has declined from $33 \%$ of Arctic Ocean sea ice to only 1.2\%. D Perovich, W Meier, M Tschudi et al., 'Sea ice', in J Richter-Menge, ML Druckenmiller and M Jeffries (eds), Arctic Report Card 2019 (NOAA, 2019) 26-34, at p. 29 .

$8 \quad$ IPCC (n 4), at p. 205.

9 Columbia Climate Center, World Wildlife Fund, Arctic 21, and Woods Hole Research Center, $A 5^{\circ} \mathrm{C}$ Arctic in $a 2^{\circ} \mathrm{C}$ World, Briefing Paper for Arctic Science Ministerial (28 September 2016), estimates warming of $3 \cdot 75^{-} 5^{\circ} \mathrm{C}$. AMAP (n 1), at p. 3, concludes that Arctic may be largely ice free in summer by late 2030 s.

11 The Arctic 'death spiral' graphic was developed by Andy Lee Robinson, https://anthro pobscene.com/arctic-death-spiral/; accessed 10 June 2020; see also 'What's the Arctic death spiral?' available at https://www.arcticdeathspiral.org; accessed 10 June 2020. 


\section{Local Effects on the Arctic}

Arctic melting will harm both human communities in the Arctic and the Arctic environment more generally.

\section{Risks to Human Communities}

Arctic warming affects human communities through two principal mechanisms: coastal erosion and thawing of the permafrost. The Arctic coastline is roughly 100,000 km long, spanning eight countries. Arctic coastal dynamics are not well understood, but one important factor that distinguishes the Arctic from temperate regions is the presence of sea ice throughout much of the year, which protects coastal areas from storms by impeding the formation and strength of waves. ${ }^{13}$ As coastal ice melts and the land become more exposed to waves and storm surges, erosion increases, causing homes to fall into the sea and roads to wash out. A 2009 US General Accounting Office study reported that 31 Alaskan native villages are imminently threatened by flooding and erosion due to climate change and that twelve are exploring relocation. ${ }^{14}$

In most of the Arctic, coastal erosion rates are already high and getting worse. On average, the Arctic coast is eroding at a rate of 0.5 metres per year, with the Beaufort sea coastline retreating more than twice as fast, the highest rate of retreat of any region of the Arctic ${ }^{15}$ and more than eight times the rate of coastal erosion in the Gulf of Mexico. ${ }^{16}$ A recent study by the Sandia National Laboratories found that 'Arctic coastal erosion rates in the United States have doubled since the middle of the twentieth century and appear to be accelerating'. It went on to conclude, '[p] ositive erosion trends have been observed for highly-variable geomorphic conditions across the entire Arctic, suggesting a major (human-timescale) shift in coastal landscape evolution. ${ }^{17}$

A second impact of Arctic warming is thawing of the permafrost, which affects inland communities, roads, pipelines, and other infrastructure by making the ground more unstable. According to the 2017 Arctic Assessment: 'The bearing capacity of building foundations has declined by $40-50 \%$ in some

13 H Lantuit, PP Overduin, N Couture et al., 'The Arctic Coastal Dynamics Database: A new classification scheme and statistics on Arctic permafrost coastlines' (2012) 35 Estuaries and Coasts 383-40o.

14 US General Accounting Office (GAO), Alaskan Native Villages: Limited Progress Has Been Made on Relocating Villages Threatened by Flooding and Erosion (GAO, Washington DC, 2009).

15 Lantuit et al. (n 13), at p. 393.

16 JM Frederick, MA Thomas, DL Bull et al., The Arctic Coastal Erosion Problem, SAND20169762 (Sandia National Laboratories, 2016), at p. 17.

17 Ibid., at p. 13. 
Siberian settlements since the 196os, and the vast Bovanenkovo gas field in western Siberia has seen a recent increase in landslides related to thawing permafrost'.18 In May 2020, thawing permafrost led to an industrial disaster in Siberia, when storage tanks failed at the Norilsk Nickel power plant, releasing more than 20,00o tons of diesel oil, reportedly, the second largest oil spill in Russian history. ${ }^{19}$

\section{Loss of Habitat}

Loss of Arctic sea ice threatens species in the region, including Pacific walrus and ringed seals. ${ }^{20}$ Polar bears, in particular, depend on sea ice to hunt seals, travel and mate, and have become the poster child for the threat posed by climate change to the Arctic. A recent study suggests that they are already showing the effects of diminishing sea ice, with lower weights and fewer babies. ${ }^{21}$ As their habitat continues to disappear, the survival of polar bears is at risk.

\section{Marine Ecosystems}

Finally, the melting of the Arctic is leading to the loss of sea-ice algae and sub-ice phytoplankton, which underpin the Arctic marine food web and are responsible for more than half of its primary production. ${ }^{22}$ Other effects of Arctic warming on marine ecosystems include diminishing salinity (due to excessive freshwater runoff from land) and rapidly increasing acidification.

\section{Global Effects}

As bad as Arctic melting is for the Arctic itself, its global effects are more concerning. As Vidar Helgesen, Norwegian Minister for Climate and the Environment, said at a NATO Parliamentary Assembly meeting, 'What happens in the Arctic doesn't stay in the Arctic.. ${ }^{23}$

\footnotetext{
18 AMAP (n 1), at p. 14.

19 I Nechepurenko, 'Russia declares emergency after Arctic oil spill', The New York Times (4 June 2020).

$20 \quad$ E Post, US Bhatt, CM Bitz et al., 'Ecological consequences of sea-ice decline' (2013) 341 Science $519-524$, at p. 520 .

21 KL Laidre, S Atkinson, EV Regehr et al., 'Interrelated ecological impacts of climate change on an apex species' (2020) 30(4) Ecological Applications, article e02071, 1-18, doi: 10.1002/ eap.2071.

22 Post et al. (n 20), at p. 520.

23 "What happens in the Arctic, does not stay in the Arctic" - climate change in the Arctic will have global consequences and cannot be ignored', NATo Parliamentary Assembly News, 17 May 2017, available at https://www.nato-pa.int/news/what-happens-arctic-doesnot-stay-arctic-climate-change-arctic-will-have-global-consequences; accessed 10 June 2020 .
} 


\section{Albedo Modification}

First, Arctic melting changes the local albedo, causing the region to absorb more solar radiation, thereby exacerbating global warming. Snow and ice reflect as much as 90\% of incoming sunlight, while water and land reflect less than $10 \% .{ }^{24}$ As bright areas of snow and ice become dark areas of water, the change in the local albedo results in a warming in global terms of $.17 \mathrm{Wm}^{2}$, the equivalent of roughly 25 years of $\mathrm{CO}_{2}$ emissions.

\section{Melting of Permafrost}

Second, Arctic permafrost stores vast quantities of carbon, ${ }^{25}$ which may be released into the atmosphere as $\mathrm{CO}_{2}$ and methane as the permafrost melts, further exacerbating global warming. Since 2007, near surface permafrost in the Arctic has warmed by more than $0.5^{\circ} \mathrm{C}$. Already, it has declined from 14 million $\mathrm{km}^{2}$ in the early twentieth century to less than 10 million $\mathrm{km}^{2}$ today. Near-surface permafrost is projected to decline by another $20 \%$ by 2040 and by as much as two-thirds by $2080 .{ }^{26}$ Last year's report on the Arctic by the US National Oceanic and Atmospheric Administration (NOAA) estimated that permafrost thawing could be releasing 300-600 million tons of carbon net per year. ${ }^{27}$ A 2017 study estimated that sensitivity of permafrost loss to global warming is four million square kilometres per degree $\mathrm{C}$ of warming. ${ }^{28}$ Another study found that thawing permafrost could lead to the release of 120 billion tonnes of carbon by 2100 , increasing global warming by about $0.3^{\circ} \mathrm{C} .{ }^{29}$

24 SJ Desch, N Smith, C Groppi et al., 'Arctic ice management' (2017) 5(1) Earth's Future 107-127.

25 Arctic permafrost soils contain $1460-1600$ billion metric tons of organic carbon, twice as much as the atmosphere and a third of the total soil carbon stored in the top three metres. T Schuur, 'Permafrost and the global carbon cycle', in Richter-Menge et al. (eds) $(\mathrm{n} 7), 5^{8-65}$, at p. 58. Some of this carbon is stored in methane hydrates in or beneath submarine permafrost, which could release 50 billion tonnes of methane as the Arctic warms, roughly twelve times the current atmospheric amounts. N Shakhova, I Semiletov, A Slyuk and D Kosmach, 'Anomalies of methane in the atmosphere over the East Siberian Shelf: Is there any sign of methane leakage from shallow shelf hydrates?' (2008) 10 Geophysical Research Abstracts EGU2008-A-01526.

$26 \quad \operatorname{AMAP}(\mathrm{n} 1)$, at p. 12.

27 Richter-Menge et al. (eds) (n 7), at p. 1; see also SM Natali, JD Watts, BM Rogers et al., 'Large loss of $\mathrm{CO}_{2}$ in winter observed across the northern permafrost region' (2019) 9 Nature Climate Change $85^{2-857}$, who estimate winter loss of 1.7 billion tonnes of carbon per year, as compared to about 1 billion tonnes of carbon uptake in the summer.

28 SE Chadburn, EJ Burke, PM Cox et al., 'An observation-based constraint on permafrost loss as a function of global warming' (2017) 7 Nature Climate Change 340-344.

29 K Schaefer, H Lantuit, VE Romanovsky et al., 'The impact of permafrost carbon feedback on global climate' (2014) 9(8) Environmental Research Letters, available at https:// iopscience.iop.org/article/10.1088/1748-9326/9/8/085003/pdf; accessed 10 June 2020. 


\section{Sea Level Rise}

Third, the melting of glaciers in Greenland and the United States and Canadian Arctic contributes significantly to sea level rise. ${ }^{30}$ Although Arctic sea ice is like an ice cube in a glass - when it melts, it does not raise the water level the melting of Arctic land-based ice adds water to the ocean and causes sea level rise. Currently, Arctic melting is responsible for about $35 \%$ of global sea level rise. ${ }^{31}$ Greenland has the second most land-based ice in the world, after Antarctica. Between 2011 and 2014, it lost roughly 375 billion tonnes of ice per year, twice as fast as the rate of loss between 2003 and 2008. If the Greenland ice sheet were to melt completely, it would raise sea levels by more than seven metres globally, inundating coastal areas. ${ }^{32}$ In addition, the effects of thermal expansion due to the warming of the ocean would add further to sea level rise.

\section{Effects on Ocean and Atmospheric Circulation}

Finally, the warming of the Arctic could affect ocean and atmospheric circulation. Arctic melting has added large amounts of fresh water to the ocean, increasing the levels of fresh water in the upper layer of the Arctic Ocean by $11 \%$ compared to the 1980-2000 average..$^{33}$ Although the effects are uncertain, if this added fresh water mixes with the Nordic seas and North Atlantic, it could affect ocean circulation patterns, potentially weakening the Gulf Stream. ${ }^{34}$ Similarly, Arctic warming is already observed to be disrupting the jet stream and leading to more weather extremes in mid-latitudes, including droughts, heat waves and wildfires. ${ }^{35}$

$30 \operatorname{AmaP}(\mathrm{n} 1)$, at p. 4, notes that Arctic melting is the 'dominant' cause of sea level rise over the last half century.

31 Ibid., at p. 3.

$32 \quad$ Ibid., at p. 4.

33 Ibid., at pp. $4-5$.

34 Ibid., at p. 5 .

35 ME Mann, S Rahmstorf, K Kornhuber et al., 'Projected changes in persistent extreme summer weather events: The role of quasi-resonant amplification' (2018) 4(10) Science Advances eaat327, available at https://advances.sciencemag.org/content/4/10/eaat3272. full.pdf; accessed 10 June 2020. The jet stream is powered by Arctic air flowing south due to the pressure differential between cold Arctic air and warmer air in mid-latitudes. As the Arctic warms, the declining temperature differential results in less Arctic air flowing south and a weaker jet stream. B Berwyn, 'Global warming is messing with the jet stream. That means more extreme weather', Inside Climate News (31 October 2018), available at https://insideclimatenews.org/news/31102018/jet-stream-climate-change-studyextreme-weather-arctic-amplification-temperature; accessed 10 June 2020. 


\section{Arctic Interventions}

What could be done to save the Arctic?

Reductions in greenhouse gas emissions, which are of critical importance to addressing climate change generally, would help limit Arctic melting in the medium term. The 2017 Arctic Assessment found that substantial emission cuts could stabilise loss of snow cover and permafrost after mid-century, albeit at significantly lower levels than today. ${ }^{36}$ But the climate system responds too slowly to emission cuts for conventional mitigation to be sufficient to save the Arctic. According to the 2017 Assessment,

The Arctic will not return to previous conditions this century under the scenarios considered. ... The near-future Arctic will be a substantially different environment from that of today, and by the end of this century Arctic warming may exceed the stability of sea ice, the Greenland ice sheet, and possibly boreal forests. ${ }^{37}$

A second option focuses on reducing emissions of black carbon. Black carbon has a much shorter atmospheric lifetime than carbon dioxide (days versus centuries), so reducing emissions produces a much quicker climate response and could buy time for carbon dioxide reductions to take effect. A 2015 report estimated that black carbon contributes about $0.5^{\circ} \mathrm{C}$ of Arctic warming, although it acknowledged considerable uncertainty..$^{38}$ In 2017, Arctic countries adopted an aspirational goal to reduce their black carbon emissions by $25-33 \%$ below 2013 levels by 2025. However, they are responsible for only about a third of black carbon's contribution to Arctic warming, ${ }^{39}$ so wider as well as stronger action is needed.

Growing recognition of the inadequacy of current efforts has led to increased interest in technological interventions that would produce a rapid climate response. One possibility would be to intervene in the global climate system in order to cool the Arctic, for example, by injecting sulphur aerosols into the stratosphere to scatter incoming sunlight, brightening marine clouds, or removing massive amounts of carbon dioxide from the atmosphere through ocean fertilisation.

\footnotetext{
$36 \quad \operatorname{AMAP}\left(\mathrm{n}_{1}\right)$, at p. 6.

37 Ibid.

38 AmAP, Arctic Climate Issues 2015: Short-Lived Climate Pollutants (AMAP, Tromsø, 2015), at p. 9 .

39 Ibid.; see also PK Quinn, A Stohl, A Arneth et al., The Impact of Black Carbon on the Arctic Climate, AMAP Technical Report No. 4 (AMAP, Tromsø, 2011), at p. 15.
} 
This article focuses instead on more limited regional interventions, interventions that are Arctic-specific in their location and immediate effects. Two types of Arctic interventions have been suggested: Arctic ice management and glacial interventions. ${ }^{40}$

But before describing these interventions, several caveats are in order. First, Arctic interventions may not be technologically feasible, given the harshness of the Arctic environment. This article considers them from a policy and legal perspective, but not from an engineering perspective. Second, Arctic interventions, even if feasible, would address only one piece of the climate change problem: the melting of the Arctic. They are not a substitute for global solutions. Third, this article suggests only that Arctic interventions be investigated as a possible means of saving the Arctic. Whether any of them should actually be undertaken would depend on what the research shows about their technological feasibility, effectiveness, scalability, timeliness and safety.

\section{Arctic Ice Management}

Arctic ice management focuses on saving Arctic ice directly, either by increasing the rate of freezing or by decreasing the rate of melting.

One proposed technique to increase freezing would be to spray seawater directly on top of the ice during the Arctic winter, when despite global warming it is still generally very cold. ${ }^{41}$ Ice is an insulator and slows the freezing of the water beneath it. Pumping water from under sea ice and spraying it on top, where it would be directly exposed to frigid air, would thus increase the rate of freezing and result in thicker ice. If Arctic sea ice were thickened in the winter, it might survive the summer and continue to reflect sunlight, rather than

40 Some have also proposed regional solar climate intervention, that is, limiting the amount of sunlight that reaches the Arctic. D Lunt, J Singarayer and A Ridgwell, 'Can geoengineering save the Greenland ice sheet?' (2009) 6 IOP Conference Series: Earth and Environmental Science 452009. Caldeira and Wood estimate that restoring September Arctic sea ice to its pre-industrial levels, in a $2 \mathrm{x} \mathrm{CO}_{2}$ world, would require a reduction of incoming sunlight by about $20 \%$ in the area north of $71^{\circ} \mathrm{N}$. K Caldeira and L Wood, 'Global and Arctic climate engineering: Numerical model studies' (2008) 366 Philosophical Transactions of the Royal Society 4039-4056, at p. 4045. They view a reduction in Arctic insolation of this scale to be feasible, but other model simulations conclude that the regional solar dimming needed to maintain Arctic sea ice 'would be very difficult to achieve'. S Tilme, A Jahn, JE Kay et al., 'Can regional climate engineering save the summer Arctic sea ice?' (2014) 41(3) Geophysical Research Letters 880-885. In any event, solar climate interventions in the Arctic would raise similar concerns to global solar climate intervention and will not be discussed further in this article. 
melting through and becoming blue water that absorbs heat and accelerates the pace of warming.

Needless to say, this proposed technique raises formidable engineering challenges and may well be infeasible. It would require an energy source to pump the water from below the ice and spray it on top. Given the high winds during the Arctic winter, one idea would be to use windmills to power the pumps. ${ }^{42}$ But the windmills and pumps would need to be extremely durable to withstand the harsh weather and sea conditions during the Arctic winter and may need to be reinstalled from one year to the next.

A second option focuses on decreasing the rate of melting of Arctic ice by spraying reflective beads on top of the ice in order to increase its albedo ${ }^{43} \mathrm{~A}$ Canadian non-governmental organisation ( $\mathrm{NGO}$ ) has developed beads made out of silicate that are highly reflective. It claims that these beads have succeeded in slowing the rate of melting in tests on Canadian lakes. Even if the beads are indeed effective in reflecting sunlight, however, the technical challenges would be formidable to cover a significant fraction of Arctic ice with beads and then replace those that are washed away in order to maintain coverage each year during the summer when melting is fastest. Moreover, before pursuing this idea, research would be needed on the potential effects of the reflective beads on Arctic species and the Arctic environment more generally.

\section{Glacial Interventions}

Between 1992 and 2018, Greenland lost roughly 4000 billion tonnes of ice. In the summer of 2019, unusually high temperatures melted 600 billion tonnes of Greenland ice, raising global sea level by more than $2 \mathrm{~mm} .{ }^{44}$ Melting of the Jakobshavn glacier in western Greenland alone has been estimated to account for roughly $4 \%$ of sea level rise in the twentieth century. 45

Scientists believe that roughly half of Greenland's ice enters the sea in 'narrow, fast-flowing ice streams. ${ }^{46}$ As these ice streams reach the sea, warmer

\section{Ibid.}

43 L Field, D Ivanova, S. Bhattacharyya et al., 'Increasing Arctic sea ice albedo using localized reversible geoengineering' (2018) 6(6) Earth's Future 882-901.

44 I Velicogna, Y Mohajerani, A Geruo et al., 'Continuity of ice sheet mass loss in Greenland and Antarctica from the GRACE and GRACE Follow-on missions' (2020) 47(8) Geophysical Research Letters e2O2OGLO87291, doi: 10.1029/2020GLo87291. In some areas, temperatures were $40^{\circ} \mathrm{F}$ above normal and, at its peak, $45 \%$ of Greenland's surface was covered in meltwater. J Gertner, 'In Greenland's melting ice, a warning on hard climate choices' Yale Environment 360 (27 June 2019).

45 JC Moore, R Gladstone, T Zwinger and M Wolovick, 'Geoengineer polar glaciers to slow sea-level rise' (2018) 555 Nature 303-305, at p. 304.

$46 \quad$ Ibid. 
sea water penetrates under their base, creating a thin layer of water or wet sediment that acts as a lubricant, causing the glaciers to slide into the sea. This lubrication effect dramatically accelerates the loss of Greenland ice, contributing to sea level rise.

Some have speculated that it would be possible to slow the slippage of glaciers into the sea by building a berm at the base of a glacier, to prevent sea water from penetrating under the glacier and lubricating its base. ${ }^{47}$ For example, one paper estimates that a 100 metre wall could be built at the five kilometre wide front of the Jakobshavn glacier by dredging o.1 cubic kilometre of gravel and sand, only about a tenth as much as was needed to build the Suez Canal and a third as much as was dredged to build the Hong Kong Airport. ${ }^{48}$

A second proposal would address another source of glacial slippage: the creation of a thin film of water at the base of glaciers due to friction with the earth as the glacier moves downhill as well as meltwater from the surface of the glacier falling through crevices to the base. If it were possible to drill through glaciers and pump out the subglacial water, this could slow the rate at which glaciers flow into the sea.

\section{How Arctic Interventions Differ from Global Climate Interventions}

The subject of climate inventions has provoked considerable controversy. Tampering with a complex, only partially understood system like the global climate could have unpredictable consequences and to many is a scary prospect. Some object even to researching the topic for fear that it would undermine efforts to reduce emissions and lead inevitably to deployment. ${ }^{49}$

We disagree with this wholesale rejection of climate interventions. Although intervening in the global climate system raises significant concerns, so too does climate change. If climate change is indeed a critical issue facing humanity, it seems irresponsible to take any option off the table before we even investigate its feasibility, effectiveness and safety.

\footnotetext{
$47 \quad$ Ibid.

48 Ibid.

49 Some argue that the technical challenges to global climate interventions are so significant that 'the governance challenge is less a "slippery slope" than an "uphill struggle". R Bellamy and P Healey, "Slippery slope" or "uphill struggle"? Broadening out expert scenarios of climate engineering research and development' (2018) 83 Environmental Science and Policy 1-10, doi: 10.1016/j.envsci.2018.01.021.
} 
But our argument in this article does not concern global climate interventions. Rather, it is that, whatever one thinks about global climate interventions, the Arctic interventions described above are different in significant respects. ${ }^{50}$

\section{Analogies to Conventional Mitigation and Adaptation}

Global climate interventions are frightening to many people because they involve trying to manipulate the climate system generally in massive and unprecedented ways. Critics cast climate interventions as playing God with nature, ${ }^{51}$ with the potential to cause unintended and possibly catastrophic consequences. For this reason, they view global climate interventions as radically different from conventional mitigation or adaptation.

But the same is not true of Arctic interventions. Consider, for example, building a berm to prevent Greenland glaciers from slipping off the continent. Assuming this were possible, it would be very different in kind from injecting sulphur aerosols into the atmosphere or fertilising the ocean with iron, both of which seek to intervene in complex natural processes with potentially unpredictable effects, in order to control the global climate system. In essence, building a berm would not be dissimilar to building a sea wall to protect against sea level rise. Both are types of adaptation, involving the construction of a barrier to prevent the damage resulting from the penetration of sea water. Only the scale of the barriers differs. States regularly build dams for reservoirs and hydroelectric power and move large amounts of earth to reclaim land, create canals, and dredge rivers and harbours, so why shouldn't they be able to build a berm to protect a glacier?

Similarly, thickening Arctic sea ice in the winter or increasing its albedo through reflective beads would not involve perturbing complex physical systems. Instead, they essentially would seek to maintain historic levels of sea ice and are analogous to conventional mitigation and adaptation measures. Refreezing sea water is analogous to reforesting trees, in that both seek to maintain an ecosystem to its existing state. Similarly, using reflective beads to make Arctic ice brighter is analogous to developing drought-resistant crops, in that both seek to protect a resource by making it hardier. If reforestation and development of drought-resistant crops are potentially acceptable climate strategies, why isn't the same true of their Arctic analogues? Why shouldn't we evaluate Arctic interventions in the same way we evaluate other climate

$50 \quad C f$. TD Hester, 'A matter of scale: Regional climate engineering and the shortfalls of multinational governance' (2013) 3 Carbon and Climate Law Review 168-176.

51 C Hamilton, Earthmasters: The Dawn of the Age of Climate Engineering (Yale University Press, New Haven, 2013) 178. 
policies - in terms of their feasibility, effectiveness, costs, and risks - rather than putting them in a separate category?

\section{Localised Scope and Effects}

Arctic interventions differ not only in kind from global climate interventions, but also in scope and effects..$^{52}$ Global climate interventions such as stratospheric aerosol injection, marine cloud brightening, and ocean fertilisation might take place outside a State's territory - for example, in the upper atmosphere or on the high seas - and would have as their purpose to manipulate the global climate. By contrast, Arctic interventions would be undertaken at the regional level (in some cases solely within a State's territory) in order to protect the Arctic environment. For example, spraying reflective particles on the Greenland ice sheet or building berms to prevent Greenland's glaciers from slipping into the sea would be undertaken solely within Greenland and would directly affect only ice located in Greenland.

\section{'Moral Hazard' Less of an Issue}

Another difference between Arctic and global climate interventions relates to the issue of 'moral hazard'. A common argument against considering global climate intervention as a policy option is that doing so will pose a moral hazard by reducing the willingness of people to undertake costly emission reductions. ${ }^{53}$ Whether this argument is valid with respect to global climate interventions is questionable. ${ }^{44}$ But whatever moral hazard is created by global climate interventions, the risk of moral hazard presented by Arctic interventions would be much less, since they address only one contributor to climate change (the positive feedbacks of Arctic melting) and are clearly not an alternative to emission reductions.

\section{Regional Governance Possible}

Finally, Arctic interventions pose less of a governance challenge than global climate interventions. Many believe that decision-making by individual countries about whether to undertake global climate interventions would be problematic, and that global governance would therefore be desirable. If so, there is no obvious institution at the global level with the necessary mandate,

$5^{2} \quad$ Hester (n 50$)$, at p. 174.

53 AC Lin, 'Does geoengineering present a moral hazard?' (2013) 40 Ecology Law Quarterly 673-712.

54 JE Aldy and R Zeckhauser, Three Prongs for Prudent Climate Policy, Resources for the Future Working Paper 20-o8 (Resources for the Future, Washington, DC, April 2020) $24-25$. 
membership and efficacy to decide whether and how to proceed. ${ }^{55}$ The UN climate change regime is one option and has had some notable successes, most prominently, the adoption of the Paris Agreement. But given its consensus decision-making rule and often contentious politics, assigning it authority over climate interventions could be a recipe for paralysis. The UN Security Council could make decisions, since climate change falls within its mandate to address issues of international peace and security ${ }^{56}$ and global climate interventions could raise security issues as well, ${ }^{57}$ but any permanent Council member could block decisions.

By contrast, if international governance is needed for Arctic interventions, ${ }^{58}$ there is an obvious institution that could play a governance role, namely, the Arctic Council. ${ }^{59}$ The Arctic Council was established in 1996 to promote cooperation and coordination among the Arctic States. It consists of the eight circumpolar Arctic countries - Canada, Denmark, Finland, Iceland, Norway, the Russian Federation, Sweden, and the United States - with six organisations representing indigenous peoples as permanent participants, and thirteen nonArctic States, thirteen intergovernmental organisations, and twelve NGOs participating as observers.

Although Arctic interventions would have global effects, they would not have setting the global temperature as their purpose. Rather, their objective would be to slow Arctic melting in order to mitigate the regional and global harms. For this reason, the Arctic circumpolar countries arguably have the primary interest in deciding whether to proceed.

Because of its relatively small size, the Arctic Council has been a relatively effective forum to develop regional policies relating to the Arctic. ${ }^{60}$ Through its Arctic Monitoring and Assessment Programme (AMAP), it has conducted

55 S Biniaz and D Bodansky, Solar Climate Intervention: Options for International Assessment and Decision-Making (Center for Climate and Energy Solutions/ SilverLining, July 2020).

56 UN Charter, Art. 24.

57 A Maas and J Scheffran, 'Climate conflicts 2.o? Climate engineering as a challenge for international peace and security' (2012) 30(4) Security and Peace 193-200.

58 International governance might not be needed for glacial interventions, since they would take place within a State's territory to protect its own resources.

59 B Egede-Nissen and HD Venema, Desperate Times, Desperate Measures: Advancing the Geoengineering Debate at the Arctic Council (International Institute for Sustainable Development, Winnipeg, 2009); T Koivurova, ECH Keskitalo and N Bankes, Climate Governance in the Arctic (Springer, New York, 2009).

6o T Koivurova and DL VanderZwaag, 'The Arctic Council at 10 years: Retrospect and prospects' (2007) 40(1) University of British Columbia Law Review 121-194; P Kankanpää and O Young, 'The effectiveness of the Arctic Council' (2012) 31(1) Polar Research 17176, doi: 10.30402/polar.v31io.17176. 
assessments of climate change on the Arctic, and adopted a ministerial declaration in 2017 calling for reductions in emissions of black carbon. Although it requires consensus (which could prove difficult given the different interests and policies of its members ${ }^{61}$ ) and does not have the authority to make binding decisions, it could serve as a forum to discuss Arctic intervention proposals, undertake assessments and make recommendations.

\section{International Law Considerations}

Legal analysis of Arctic interventions depends in part on the location of the interventions. Some interventions might take place on land, for example, spraying reflective particles on Canadian snow or Greenland ice, in order to limit melting, or drilling holes through glaciers to pump out subglacial water. Other interventions might take place at sea, for example, pumping water from beneath sea ice and spraying it on top, in order to thicken the ice. Both land and sea-based interventions would be governed by international environmental law, with sea-based interventions by the law of the sea as well.

\section{Land-based Interventions}

International environmental law imposes relatively modest duties on what a State may do within its own territory. The primary obligation is the so-called 'duty to prevent' significant transboundary pollution, which has been called the 'cornerstone' of international environmental law. ${ }^{62}$ The duty was first expressed in the Trail Smelter case, in which an arbitral tribunal concluded that 'no state has the right to use or permit the use of its territory in such a manner as to cause injury ... in or to the territory of another or the properties or persons therein, when the case is of serious consequence. ${ }^{63}$ The rule was extended to apply to pollution of the global commons in Principle 21 of the

61 Russia, in particular, might object to proposals to refreeze the Arctic Ocean, given its interest in developing the Northern Sea Route. 'Moscow adopts 15-year grand plan for Northern Sea Route', Moscow Times (2 January 2020), available at https://www.themos cowtimes.com/2020/o1/o2/moscow-adopts-15-year-grand-plan-for-northern-sea-route -a68798; accessed 10 June 2020. However, Russia might also have an interest in working through the Arctic Council to ensure that refreezing activities by other Arctic States are done in such a way as not to block the Northern Sea Route.

62 G Handl, 'Transboundary impacts', in D Bodansky, J Brunnée and E Hey (eds), The Oxford Handbook of International Environmental Law (Oxford University Press, Oxford, 2007) 531-549, at p. 548.

63 Trail Smelter case (United States v. Canada), (1941) 3 UN Rep. Int'l Arbitral Awards 1905, at p. 1965 . 
1972 Stockholm Declaration on the Human Environment (later reiterated in Principle 2 of the Rio Declaration on Environment and Development), which provides that States have 'the responsibility to ensure that activities within their jurisdiction and control do not cause damage to the environment of ... areas beyond the limits of national jurisdiction.64 The International Court of Justice (ICJ) declared that this principle is 'part of the corpus of international law relating to the environment' in its Nuclear Weapons Advisory Opinion, ${ }^{65}$ and has interpreted it as an obligation to use 'due diligence' to 'avoid activities ... causing significant damage to the environment of another State. ${ }^{66}$ As a corollary of the duty to prevent, the ICJ has held that States also have various procedural duties, including the duty to undertake an environmental impact assessment when a proposed activity 'may have a significant adverse impact in a transboundary context', 67 and to notify and consult with potentially affected States if the assessment 'confirms' that a planned activity has a risk of significant transboundary harm. ${ }^{68}$

Whether these pronouncements by the ICJ about the rules of international environmental law are correct is open to debate. Judgments of the ICJ are not a formal source of international law, ${ }^{69}$ so the question is whether they accurately reflect State practice and opinio juris. Be that as it may, exercising due diligence

64 Report of the United Nations Conference on Environment and Development (Rio de Janeiro, 3-14 June 1992) UN Doc A/CONF.151/26, Annex I: Rio Declaration on Environment and Development.

65 Legality of the Threat or Use of Nuclear Weapons, Advisory Opinion, ICJ Reports 1996, p. 226, at pp. 241-242, para 29

66 Pulp Mills on the River Uruguay (Argentina v. Uruguay), Judgment, ICJ Reports 2010, p. 14, at p. 55, para 101. In its Draft Articles on Prevention of Transboundary Harm, the International Law Commission (ILC) interpreted due diligence as requiring a State to take 'all appropriate measures'. ILC, 'Draft Articles on Prevention of Transboundary Harm from Hazardous Activities', in Report of the International Law Commission on the Work of Its 53 rd Session, at p. 146, Art. 3, comments 7 and 8. In contrast, in Pulp Mills, the International Court of Justice used the formulation, 'all means at its disposal'. Pulp Mills, at pp. 55-56, para 101.

67 Pulp Mills, ibid., at p. 83, para 204; see also Responsibilities and Obligations of States with Respect to Activities in the Area, Advisory Opinion, 1 February 2011, ITLOS Reports 2011, p. 5o, at para 145, which confirmed existence of a customary obligation to conduct an environmental impact assessment, as well as an obligation under Article 206 of the UN Convention on the Law of the Sea.

68 Certain Activities Carried Out by Nicaragua in the Border Area (Costa Rica v. Nicaragua) and Construction of a Road in Costa Rica along the San Juan River (Nicaragua v. Costa Rica), Judgment, ICJ Reports 2015, p. 665, at p. 724, para 168.

69 ICJ Statute, Art. 38(1)(d) (judicial decisions are a 'subsidiary means for the determination of rules of law', not a formal source of law), Art. 59 (decisions of the Court have no binding force except between the parties). 
to prevent significant transboundary harm, undertaking environmental assessments, and consulting with potentially affected States arguably represent sound public policy, so Arctic States would be well advised to apply these rules, whether or not they represent binding obligations under international law.

How do these norms apply to Arctic interventions? If successful, Arctic interventions would clearly have global as well as local effects. Indeed, one of their primary motivations would be to ameliorate global warming by maintaining the Arctic's albedo and limiting the release of greenhouse gases caused by the thawing of permafrost. But if these are the only transboundary effects of Arctic interventions, international environmental norms would not impose any limitations since the Arctic interventions would not materially differ from other measures a State takes within its own territory to mitigate climate change.

As for other possible transboundary impacts, there has been very little research, to date, on possible Arctic interventions, so further research is needed on whether they might have significant adverse impacts on other States or on areas of the global commons. If this research indicated that Arctic interventions may have a significant adverse impact, then a State would need to conduct an environmental impact assessment before proceeding and consult with potentially affected States, although it would not ultimately need permission from other States in order to undertake the intervention.

Finally, international human rights law arguably establishes participatory rights for local communities, in particular, a right of access to information and a right to participate in decisions that may have a significant effect on the environment. ${ }^{70}$ Moreover, if an Arctic intervention had significant adverse impacts on local communities, then this could implicate human rights law (for example, rules relating to indigenous rights, given that about $10 \%$ of Arctic residents are indigenous peoples).

70 These rights are provided as a matter of treaty law in the Aarhus Convention on Access to Information, Public Participation in Decision-Making and Access to Justice in Environmental Matters (Aarhus, 25 June 1998, in force 30 October 2001 ), 2161 UNTS 447, to which Denmark, Finland, and Norway are parties. The UN Special Rapporteur on Human Rights and the Environment included the right to public participation in his Framework Principles, which purport to reflect 'the application of existing human rights obligations in the environmental context'. Report of the Special Rapporteur on the issue of human rights obligations relating to the enjoyment of a safe, clean, healthy, and sustainable environment, UN Doc A/HRC/37/59 (24 January 2018), para 8. 


\section{Ocean-based Interventions}

Additional legal issues would be raised by interventions undertaken in the Arctic Ocean rather than on land, since the rights of other States to freedom of navigation or innocent passage might be implicated by efforts to thicken sea ice or to retard its melting. In 2008, the five coastal States bordering on the Arctic Ocean (Canada, Denmark (Greenland), Norway, the Russian Federation, and the United States) adopted the Ilulissat Declaration, which reaffirmed their commitment to the legal framework provided by the law of the sea, including its provisions on the protection of the marine environment, freedom of navigation and marine scientific research. ${ }^{71}$ In light of this 'extensive' legal framework, the five Arctic coastal States saw 'no need to develop a new comprehensive legal regime to govern the Arctic Ocean'.

Under the law of the sea, the legal analysis of Arctic climate interventions would depend on where the intervention takes place:

- Within their territorial sea (that can extend 12 nautical miles from shore ${ }^{72}$ ), coastal States have sovereignty, ${ }^{73}$ but ships of other States have a right of innocent passage. ${ }^{74} \mathrm{~A}$ coastal State may adopt laws and regulations for the preservation of the environment and has the exclusive right to conduct marine scientific research, ${ }^{75}$ but may not 'hamper the innocent passage of foreign ships through the territorial sea. ${ }^{76}$

- In their exclusive economic zones (which may extend up to 200 miles from the coastal State's baseline), coastal States have the sovereign right to conserve the natural resources of the waters superjacent to the seabed, as well as jurisdiction with regard to the protection and preservation

71 Ilulissat Declaration, Arctic Ocean Conference, adopted 28 May 2008, available at https:// arcticportal.org/images/stories/pdf/Ilulissat-declaration.pdf; accessed 10 June 2020. In the Ilulissat Declaration, the five Arctic coastal States also noted that the Arctic is a 'unique ecosystem' and announced that they would 'take steps in accordance with international law both nationally and in cooperation among the five states and other interested parties to ensure the protection and preservation of the fragile marine environment of the Arctic Ocean'. However, the Declaration focused on ship-based pollution, tourism, and resource development, rather than on the effects of climate change on the Arctic or on possible interventions to ameliorate those impacts.

Where coasts are irregular, the UN Convention on the Law of the Sea provides extensive rules to determine the 'baseline' from which the breadth of the territorial sea, contiguous zone, exclusive economic zone and continental shelf are measured. United Nations Convention on the Law of the Sea (Montego Bay, 10 December 1982, in force 16 November 1994), 1833 UNTS 3, Arts 5-14 [LOSC].

73 Ibid., Art. 2.

74 Ibid., Art. 17.

75 Ibid., Arts. 21, 245 .

76 Ibid., Art. 24. 
of the marine environment and marine scientific research, ${ }^{77}$ but other States have the right to freedom of navigation. ${ }^{78}$ In exercising these rights, both the coastal State and other States must have 'due regard' to the rights of the other ${ }^{79}$ Although States may not conduct marine scientific research in another State's EEZ without its consent, the United Nations Convention on the Law of the Sea (LOSC) provides that coastal States 'shall, in normal circumstances, grant their consent'. ${ }^{80}$

- Finally, on the high seas, any State may take actions to protect the environment and may conduct scientific research, but again must do so with due regard to the high seas freedoms of other States, including freedom of navigation. ${ }^{81}$

These provisions answer some questions regarding Arctic climate interventions, but raise others:

- With respect to marine scientific research on Arctic interventions, each Arctic coastal State has the exclusive right to conduct research in its territorial sea; an Arctic coastal State could disallow research by another State within its EEZ only for narrowly specified reasons; and any State could undertake scientific research on Arctic interventions in the high seas portions of the Arctic Ocean, so long as the research did not interfere with freedom of navigation.

- If a coastal State's refreezing of its territorial sea (e.g., to protect its coastline from Arctic storms) completely prevented transit by foreign ships, this might run afoul of Article 24 of the LOSC, which prohibits coastal States from 'hampering' the innocent passage of foreign ships. ${ }^{82}$ Similarly, Arctic interventions in a coastal State's EEZ and on the high seas portion

$77 \quad$ Ibid., Art. 56(1).

78 Ibid., Art. 58(1). The LOSC also gives coastal States greater authority to adopt and enforce laws and regulations to prevent, reduce and control marine pollution from vessels in icecovered areas of their EEzs, so long as the laws and regulations are non-discriminatory. Ibid., Art. 234. But this provision - the only one in the LOSC that specifically addresses icecovered areas - does not appear relevant to Arctic climate interventions, since it focuses on the hazards to navigation created by sea ice, which increase the risk to the marine environment from vessel-source pollution, rather than on any coastal State interest to conserve and preserve sea ice in its EEz.

79 Ibid., Arts. 56(2), 58(3).

8 o Ibid., Art. 246.

81 Ibid., Art. 87. To the extent environmental protection on the high seas would infringe on high seas freedoms, such as freedom of navigation or the freedom to fish, then international agreement would be needed, as is being negotiated currently on protection of biodiversity in areas beyond national jurisdiction.

Ibid., Art. 24(1). 
of the Arctic Ocean would need to have 'due regard' to freedom of navigation. ${ }^{83}$

- Refreezing sea ice in another State's EEz would arguably conflict with the coastal State's jurisdiction over the protection and preservation of the marine environment. ${ }^{84}$ In addition, if sea ice were considered a 'natural resource', then coastal States would have the sovereign right to conserve and manage it within their EEZ, which would preclude other States from doing so. ${ }^{85}$

- The law of the sea does not specifically deal with whether preventing the melting of sea ice in areas not historically navigable might be considered to constitute interference with freedom of navigation and, if so, how it might be undertaken with due regard to the navigational rights of other States. But the regime relating to artificial islands may provide a relevant analogy. The law of the sea gives coastal States the exclusive right to construct artificial islands within their EEZ and allows any State to construct artificial islands on the high seas. ${ }^{86}$ Although the freedom to construct artificial islands on the high seas must have 'due regard' to the freedom of navigation of other States, ${ }^{87}$ the right of coastal States to construct artificial islands in their EEZ is limited by freedom of navigation only when it would interfere with 'the use of recognized sea lanes essential to international navigation' ${ }^{88}$ To the extent refreezing sea ice is analogous to constructing an artificial island, then the law of the sea would limit a coastal State's right to refreeze its EEZ only if there were 'recognized sea lanes essential to international navigation' in its EEZ with which the refreezing would interfere.

- Finally, it is worth noting that refreezing sea ice would not appear to directly affect the baselines of coastal States or raise issues in that regard.

\section{Conclusion}

The Arctic plays a key role in the climate system, it is deteriorating quickly, and we have few options to save it. These are the unfortunate facts. In the long run, decarbonisation of the global economy is essential in order to avoid

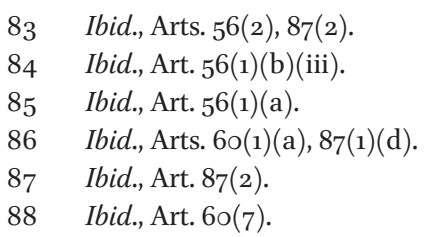


dangerous climate change. But, no matter how quickly it occurs, it will likely not be enough to save the Arctic. By the time the climate system responds, the Arctic as we know it will likely be gone.

The desperate plight of the Arctic has led some to suggest novel responses, involving the use of technology to refreeze sea ice, increase the reflectivity of snow and ice, or buttress glaciers. These technological interventions, even if fully effective, would not solve the climate change problem or save the Arctic in the long term. But they could serve as a stopgap, to preserve Arctic ice while the effects of emission reductions work their way through the climate system.

The technologies in question are highly speculative. Further research is needed to assess their feasibility, effectiveness, scalability, timeliness and safety. But they should not be rejected solely because they represent technological interventions in the climate system. Whatever one thinks about global climate interventions such as stratospheric aerosol injection or marine cloud brightening, Arctic interventions differ in material respects. They are closer in kind to conventional mitigation and adaptation and should be evaluated on similar terms. 